\title{
In Vitro Antibacterial Activity from Marine Algal Extracts
}

\section{Against Virulent Bacteria}

Khouloud M. I. Barakat*, Hermine R. Z. Tadros**

\begin{abstract}
In vitro screening using methanolic extracts of different marine algae and one sea grass showed antibacterial activity against eight virulent strains of fish and human pathogens. 1:1 (V: V) ratios of each methanolic extract were mutually added to give 21 interactions. The interaction between Udotea sp and Codium fragile extracts exhibited higher activities against Edwardsiella tarda $(18 \pm 0.9 \mathrm{~mm})$, Vibrio ordalli $(16 \pm 0.8 \mathrm{~mm})$, Klebsiella pneumonia $(20 \pm 1 \mathrm{~mm})$ and Pseudomonas aeruginosa $(16 \pm 0.8 \mathrm{~mm})$. The bioactivity of this interaction was found to be more effective than that obtained from some common antibiotics including: Lincolin, Streptomycin and Gentamycin. The chemical constituents of these two algal extracts and their interaction were characterized using thin layer chromatography and gas chromatographic - mass spectral analysis. The bioactivity of the separated compounds was estimated. Palmitic acid was the most active fatty acid.
\end{abstract}

Keywords: Algal extract interactions; Pathogenic bacteria; Antibacterial activity; Gas chromatography -Mass spectrum.

\section{INTRODUCTION}

Many bacteria cause infections in humans

difficult to deal with effectively. Klebsiella

pneumonia; for instance; was implicated in

hospital-acquired urinary tract and

wound infections. ${ }^{1} \quad$ Also; Pseudomonas pathogen among burned patients and is capable of causing life-threatening illnesses. $^{2}$ In addition; some clinical and epidemiological studies suggested that Escherichia coli and Staphylococcus aeruginosa is an important and prevalent aureus infectious diseases are the main "Marine Microbiology Lab., Division of Marine Environment, National Institute of Oceanography \& Fisheries, Alexandria, Egypt.

${ }^{* *}$ Marine Chemistry Lab., Division of Marine Environment, National Institute of Oceanography \& Fisheries, Alexandria, Egypt. 
causes for human mortality. ${ }^{3}$

The most common bacterial diseases in farmed and wild culture fish population was Edwardsiellosis caused by Edwardsiella tarda which also has a broad host range and causes diseases in humans. ${ }^{4} \quad$ Although rare; human Edwardsiella tarda infections can have diverse clinical manifestations and moreover may cause severe and lifethreatening infections. ${ }^{5}$ In addition to that; septicemia caused by Aeromonas sp. ${ }^{6}$; and Vibriosis caused by Vibrio sp. are considered as a potentially serious; common systemic disease of many cultured aquarium. $^{7}$

Preventing disease outbreaks or treating the disease with drugs or chemicals tackles these problems. Nowadays; antibiotics used for both human and animals have been increased significantly due to heavy infections and the appearance of new resistant pathogenic strain of bacteria. ${ }^{8}$ Decreased efficiency and resistance of pathogen to antibiotics has necessitated the development of new alternatives. ${ }^{9}$

Many bioactive substances have been isolated from algae. ${ }^{10}$ Choudhury; et al. ${ }^{11}$ studied in vitro the screening of organic solvent extracts of three marine algae (Gracilaria corticata; Ulva fasciata and Enteromorpha compressa) which inhibited the growth of six virulent strains of fish pathogenic bacteria: Edwardsiella tarda; Vibrio alginolyticus; Pseudomonas fluorescens; Pseudomonas aeruginosa and Aeromonas hydrophila.

In addition; Kandhasamy and Arunachalam $^{12}$ showed that methanolic crude extracts of Indian seaweeds belonging to Chlorophyceae; Rhodophyceae and Phaeophyceae were active only against Klebsiella pneumonia; Enterobacter aerogens; Escherichia coli; Pseudomonas aeruginosa; Micrococcus luteus; Enterobacter faecalis; Streptococcus faecalis; Staphylococcus aureus and 
Bacillus subtilis.

Another investigation by Abd El-Baky; et $a l .^{13}$ showed the antibacterial activity of the methanolic extracts of Ulva latutus collected from the Mediterranean sea of the Egyptian coast against six pathogenic bacterial strains; Bacillus subtilis; Bacillus cereus; Staphylococcus aureus; Micrococcus Iuteus; Klebsiella pneumoniae; Serratia marcescencs. Ibtissam et al. ${ }^{14}$ studied the antibacterial activity of microalgae methanolic extracts against Escherichia coli; Staphylococcus aureus; Enterococcus faecalis and Klebsiella pneumonia.

As extension; the goal of this work is to study the bioactivity produced by some Egyptian marine algal species against some human and fish pathogens. Also we investigated the in vitro higher activity produced by the interactions between the two potent algal extract against these clinical bacterial pathogens. Chemical characterization of the potent extracted products was studied and the bioactivity of the separated compounds was estimated.

\section{MATERIALS AND METHODS}

\section{Algae Samples Collection}

Marine algae were collected by hand picking from Abu-Qir Bay in March 2009. The collected algae were identified by Dr. Mary Gendi; Professor of aquatic plant; marine environment division; National Institute of Oceanography and Fisheries (NIOF) as: Chlorophyta group: (1) Udotea sp.; (2) Codium dichotomum; (3) Codium fragile; (4) Codium vermilaria. Rhodophyta group: (5) Corallina mediterranea; (6) Corallina elangata and one Sea grass (7) Posidonia sp.

\section{Algae Samples Preparation}

Algal samples were transported to the laboratory in sterile polyethylene bags at $0^{\circ} \mathrm{C}$ temperature. Samples were cleaned of epiphytes and extraneous matter by washing with sterile seawater several times. In the laboratory; the cleaned algae were sun dried followed by oven drying at 
$60^{\circ} \mathrm{C}$ to constant dry weight for two hours.

The dried algae were milled and sieved.

The algae mesh size was 100-150 $\mu \mathrm{m}$.

\section{Extract Procedure}

Fifteen $\mathrm{g}$ of the algal powdered samples was extracted in $150 \mathrm{ml}$ pure methanol twice by soaking for overnight at room temperature $\left(25^{\circ} \mathrm{C}\right)$. The extracts from two consecutive soaking were pooled and evaporated under vacuum pressure to obtain the residues (crude extracts). The methanolic crude extracts were tested for their antibacterial activity against the pathogens used in the present investigation.

\section{Test Organisms}

The antibacterial evaluation was performed using some fish pathogens: Aeromonas hydrophila; Edwardsiella tarda; Vibrio ordilli and Yersinia ruckeri that were isolated and identified by the Department of Fish diseases and Hygiene; Faculty of Veterinary Medicine; Alexandria University; Egypt; and some human pathogenic bacteria such as: Klebsiella pneumonia; Escherichia coli; Pseudomonas aeruginosa; and Staphylococcus aureus that were kindly provided by the Department of Botany and Microbiology; Faculty of Science; Alexandria university; Egypt. These pathogens were cultured individually on tryptic soya broth at $30^{\circ} \mathrm{C}$ for 18h; before inoculation for assay. Adequate amounts of inoculated Tryptic Soya Agar (TSA) medium with the tested strains were dispensed into sterile plates and allowed to solidify under aseptic conditions.

\section{Antibacterial Assays}

The bioactivity of different algal extract was estimated using the disc diffusion assay according to Kirby-Bauer bioassay technique. $^{15}$ Sterile discs $(6 \mathrm{~mm}$ in diameter) were immersed in each algal extract $(10 \mu \mathrm{l} /$ disc each contain at least 100 $\mu \mathrm{g}$ crude) using alcohol sterilized forceps and allowed to dry; then; placed on previously prepared TSA plates containing 
the tested pathogens $\left(10^{6} \mathrm{CFU} / \mathrm{ml}\right)$. The plates were allowed to diffuse for $6 \mathrm{~h}$ in the refrigerator then incubated at $30^{\circ} \mathrm{C}$ for 24 48h. After incubation; all plates were observed for inhibition zones; the diameters of which were then measured. The diameters of the inhibitory activity caused by methanol were also tested. All tests were carried out under sterile conditions in duplicate.

\section{Algal Extract Interactions}

In vitro interactions were performed to evaluate the antibacterial activities of the combination of two-algal extracts against the tested pathogens. Screening of $1: 1$ $(\mathrm{V} / \mathrm{V})$ of 21 algal extract combinations was carried out by immersing sterile discs in each interaction then; placing on the TSA medium with the tested bacteria. Three antibiotic-containing discs (Gentamicin;

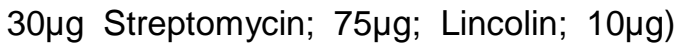
were used to compare the inhibition of the tested organisms with the bioactivity produced by the interactions. ${ }^{16}$ All the above data were recorded as standard error using ORIGIN software (ver.6.1; ed. 2000).

\section{Characterization of the Methanol Algal}

\section{Crude Extract}

\section{Thin layer chromatography}

The crude extracts were monitored using silica gel TLC plates. Silica gel plates (60GF254; size $20 \times 20 \mathrm{cmm}$; thickness 0.25 $\mathrm{mm}$; Merck) were spotted with the extracted product and developed with methanol solvent. After methanol evaporation; the plates were observed under UV-lamp; then the numbers of spots were counted and the values of the retardation factor $\left(\mathrm{R}_{f}\right)$ were calculated. Separated spots of each compound were scratched; dissolved in methanol and applied on discs where the solvent was evaporated. The bioassay was carried out using the tested pathogens.

Gas chromatographic-mass spectrometric analysis

Analysis was conducted using an HP 
(Hewlett Packard; 5890 GC hyphenated with 5989 Mass Spectrometer). MS conditions were as follows: Detector mass spectrometer voltage $70 \mathrm{eV}$ and its source temperature was $300^{\circ} \mathrm{C}$. The injector temperature was $240^{\circ} \mathrm{C}$ and the splitless mode $0.5 \mu \mathrm{L}$ injection. The HP-5MS (5\% dimethyl-95\% diphenylpolysiloxane nonpolar column was performed with length 30 $\mathrm{cm} \times 0.25 \mathrm{~mm}$ i.d.; coating thickness film $0.25 \mu \mathrm{m}$. The carrier gas was Helium $(\mathrm{He})$ with a flow rate of $1 \mathrm{ml} / \mathrm{min}$. The oven was adjusted at $70^{\circ} \mathrm{C}$ for an initial time of $1 \mathrm{~min}$ with $40^{\circ} \mathrm{C}$ and ending with a final temperature of $290^{\circ} \mathrm{C}$; the hold time was 4 min and the total run time was $15 \mathrm{~min}$. The components were identified by comparing their retention times to those of authentic samples; as well as by comparing their mass spectra with those of Wiley 275 Library. ${ }^{17}$ Quantitative data were obtained by the peak normalization technique using integrated FID (Flam ionized detector) response.

\section{RESULTS AND DISCUSSION}

Many marine algae exhibit antibacterial activity that varies between species. ${ }^{18}$ In the present study; the inhibition of some fish and human pathogens by different methanolic marine algal extract was demonstrated. The two methanolic green algal extract of Udotea sp. and Codium fragile were found to have higher activities against the tested pathogens than the collected individual of red algae. This was in agreement with Salvador et al. ${ }^{19}$ who screened many species of algae for their antibacterial activity and found that green algae (Chlorophyceae) were the most active; even the members of the red algae (Rhodophyceae) showed high antibacterial activity.

Antimicrobial Activity of Different Algal

\section{Extract}

In the present investigation; extracts of marine algal species were tested against the bacterial pathogens by agar diffusion 
method. The results of preliminary screening tests are summarized in Table 1; which revealed that all algal species possessed different levels of antibacterial activity. A. hydrophila; Y. ruckeri; E. coli and $S$. aureus were shown to be more or less resistant to some methanolic algal extracts. On the other hand; E. tarda; $P$. aeruginosa; V. ordilli and $K$. pneumonia were susceptible to all extracts; except for the two former bacteria which were resistant to Posidonia $\mathrm{sp}$ and Codium dichotomum extracts; respectively. E. tarda was highly inhibited by the Udotea extract with a diameter zone of $17 \mathrm{~mm}$. This was followed by the susceptibility of Klebsiella pneumonia to Codium fragile extract (16mm). Choudhury et al. ${ }^{11}$ reported that the activity against some virulent fish pathogenic bacteria using the methanolic algal extracts caused an inhibition zone of $12 \mathrm{~mm}$ against $V$. alginolyticus but no activity was detected against $E$. tarda. Moreover; Kandhasamy and
Arunachalam ${ }^{12}$ recorded activities against K. pneumonia and $P$. aeruginosa of 15 and $14 \mathrm{~mm}$ from Caulerpa racemosa and of 12 and $13 \mathrm{~mm}$ from Ulva lactua methanolic extracts. However; Ibtissam et al. ${ }^{14}$ reported the absence of an activity against both $K$. pneumonia and $P$. aeruginosa from marine Codium dichotomum extract.

\section{Antimicrobial activity using different} algal interactions

Further screening was carried out using the interaction of extracted algae to study the synergistic effect of their combinations on the tested pathogens. It was shown that the highest zones of inhibition were observed for Udotea sp: Codium fragile (1:3 interactions) with $18 \pm 0.9$ and $20 \pm 1 \mathrm{~mm}$ against $E$. tarda and K. pneumonia; respectively. Also; the bioactivity produced against $V$. ordilli and $P$. aeruginosa was recorded with $16 \pm 0.8 \mathrm{~mm}$ for both pathogens. In the mean time; the growth of these pathogens was found to be inhibited by Lincolin; 
Streptomycin and Gentamicin at levels lower than that observed by this interaction; except for Streptomycin and Gentamicin which exhibited slightly higher activities of $17 \pm 0.85$ and $18 \pm 0.9 \mathrm{~mm}$ against $V$. ordilli and $P$. aeruginosa; respectively (Table 2). Similarly; Choudhury et al. ${ }^{11}$ reported higher activities produced by Streptomycin and Gentamicin; 20 and $15 \mathrm{~mm}$ against $V$. angularuim and $E$. tarda; respectively compared with some methanolic algal extracts. Moreover; Kandhasamy and Arunachalam ${ }^{12}$ reported that the activities of Chloramphenicol against $P$. aeruginosa $(14 \mathrm{~mm})$ and $K$. pneumonia $(9 \mathrm{~mm})$ were lower than the antimicrobial effect produced by Caulerpa racemosa extract $(15 \mathrm{~mm})$.

\section{Chemical characterization}

TLC chromatography was carried out using methanol as a solvent which caused the separation of two colored spots from Udotea sp. extract followed by one spot from Codium fragile and another two colored spots from their interaction. The two first spots were observed at $R_{f} 0.90$ and 0.73 and the Codium fragile extract spot was detected at $\mathrm{R}_{f}$ 0.68. Moreover; the interaction showed $R_{f}$ values of 0.96 and 0.64 (Table 3).

The Gas Chromatographic analysis illustrated in Figure 1; revealed a high concentration of methyl isostearate (91\%) and much lower amounts of palmitic acid (53\%) in Udotea extract (Figure 2). In addition; extract from Codium fragile showed the presence of hexadecanoic acid; methyl ester (93\%) as seen in Figure 3. This was followed by the highest amounts of hexadecanoic acid; methyl ester (90\%) and palmitic acid (95\%) in their interaction (Figure 4). The chemical properties of the five GC/MS obtained compounds are represented in Table 3.

\section{Antibacterial activity of the separated compounds}

The bioactivity of the separated spots were checked up and the inhibitory activity 
against the tested pathogens was notable

(Table 4). There is an evidence that palmitic acid separated from the interaction; is responsible for the bioactivity against E. tarda; V. ordilli; K. pneumonia and $P$. aeruginosa compared with the other fatty acids; where the recorded inhibition zones were of $18 ; 15 ; 15$ and $13 \mathrm{~mm}$; respectively. It seems that; the presence of hexadecanoic acid methyl ester enhanced the antibacterial activity of palmitic acid in the interaction especially that it didn't cause any inhibition zone against $V$. ordilli and hence might be the cause of the increase in most of the diameters of the palmitic acid inhibition zones in the interaction which were lower in Udotea sp. (Figure 5). Using the same spectroscopic analysis; palmitic acid and short chain fatty acids obtained from Himanthalia elongate end $^{20}$ and Haematococcus pluvialis ${ }^{21}$ extracts produced higher antibacterial activity against some tested pathogens which exhibited inhibition zones that ranged from
$10-13.5 \mathrm{~mm}$ and 6 to $16 \mathrm{~mm}$; respectively.

\section{CONCLUSION}

From these results; we can conclude that the interaction between Udotea $\mathrm{sp}$. and Codium fragile had the best antibacterial activity against two fish pathogens; E. tarda and $V$. ordilli and two human pathogens; $K$. pneumonia and $P$. aueroginosa. Spectral analysis of such interaction confirmed that the most active component was palmitic acid which was responsible for the bioactivity and that the interaction was shown to be more active compared to its individual components. Therefore; it is promising to use this interaction as a lead molecule in drug discovery for inhibiting these pathogenic strains.

Acknowledgement: We'd like to express our sincere thanks to Dr. Magdy Khalil Soliman;Professor of Fish diseases and Hygiene; Vice dean of Faculty of Veterinary Medicine; Alexandria Uni.; also; vesity; Egypt the Marine Chemistry Lab. Members(NIOF) for their help in the extraction proces 
Table 1: Bioactivity of different algal extracts against some human and fish pathogens using agar diffusion method

\begin{tabular}{|c|c|c|c|c|c|c|c|c|c|}
\hline \multirow[b]{3}{*}{$\begin{array}{l}0 \\
\text { O }\end{array}$} & \multirow[b]{3}{*}{ 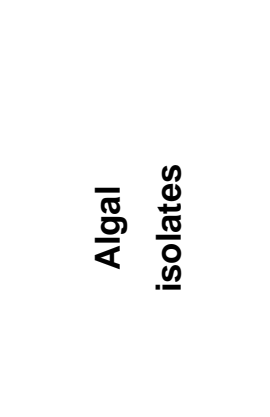 } & \multicolumn{8}{|c|}{ Inhibition zone diameter (mm) } \\
\hline & & \multicolumn{4}{|c|}{ Fish pathogens } & \multicolumn{4}{|c|}{ Human pathogens } \\
\hline & & $\frac{\frac{\pi}{\pi}}{\frac{\pi}{\pi}}$ & 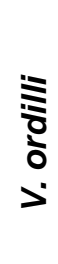 & 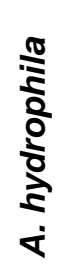 & 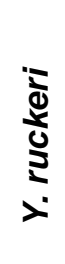 & 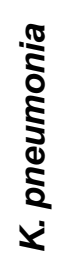 & 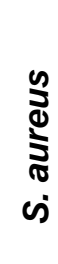 & $\begin{array}{l}\text { ठे } \\
\text { uं }\end{array}$ & 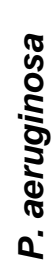 \\
\hline 1 & Udotea sp. & 17 & 12 & - & - & 12 & 10 & 10 & 13 \\
\hline 2 & C.dichotomum & 9 & 10 & 12 & - & - & 12 & - & 9 \\
\hline 3 & C. fragile & 12 & 10 & 11 & 9 & 16 & - & 10 & 13 \\
\hline 4 & C. vermilaria & 10 & 12 & - & - & 12 & 10 & 12 & 12 \\
\hline 5 & C.mediterranea & 9 & 9 & - & - & 12 & - & - & 12 \\
\hline 6 & C. elangata & 12 & 12 & - & - & 12 & - & - & 11 \\
\hline 7 & Posidonia sp & 13 & - & 10 & 10 & 12 & 10 & 13 & 11 \\
\hline
\end{tabular}


Table 2: Bioactivity spectrum of algal extracts synergy against some fish and human pathogens compared with some common antibiotics

\begin{tabular}{|c|c|c|c|c|c|c|c|c|}
\hline \multirow{3}{*}{ Algal extract } & \multicolumn{8}{|c|}{ Inhibition zone diameter $(\mathrm{mm})^{\star}$} \\
\hline & \multicolumn{4}{|c|}{ Fish pathogens } & \multicolumn{4}{|c|}{ Human pathogens } \\
\hline & 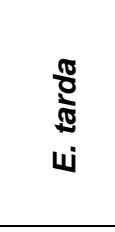 & 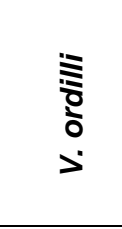 & 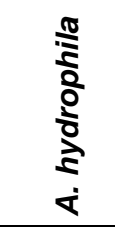 & خ & 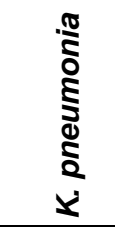 & 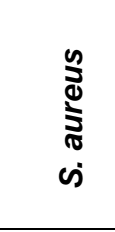 & $\begin{array}{l}\text { ठे } \\
\text { uं }\end{array}$ & 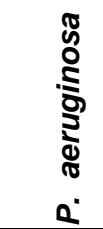 \\
\hline 1:2 & $14 \pm 0.7$ & $12 \pm 0.6$ & - & - & $16 \pm 0.8$ & $10 \pm 0.5$ & $11 \pm 0.6$ & $13 \pm 0.7$ \\
\hline $1: 3$ & $18 \pm 0.9$ & $16 \pm 0.8$ & $15 \pm 0.8$ & $11 \pm 0.6$ & $20 \pm 1$ & $15 \pm 0.8$ & $13 \pm 0.7$ & $16 \pm 0.8$ \\
\hline $1: 4$ & $12 \pm 0.6$ & $12 \pm 0.6$ & - & - & $13 \pm 0.7$ & - & - & $15 \pm 0.7$ \\
\hline 1:5 & $15 \pm 0.8$ & $15 \pm 0.8$ & $12 \pm 0.6$ & - & $13 \pm 0.7$ & $11 \pm 0.6$ & $9 \pm 0.5$ & $15 \pm 0.7$ \\
\hline $1: 6$ & $14 \pm 0.7$ & $12 \pm 0.6$ & - & - & $17 \pm 0.9$ & - & - & $13 \pm 0.7$ \\
\hline $1: 7$ & $14 \pm 0.7$ & $13 \pm 0.7$ & - & - & $15 \pm 0.8$ & $11 \pm 0.6$ & $12 \pm 0.6$ & $14 \pm 0.7$ \\
\hline $2: 3$ & $12 \pm 0.6$ & $11 \pm 0.6$ & $11 \pm 0.6$ & $10 \pm 0.5$ & $12 \pm 0.6$ & $8 \pm 0.4$ & $11 \pm 0.6$ & $15 \pm 0.7$ \\
\hline $2: 4$ & $11 \pm 0.6$ & $9 \pm 0.5$ & $9 \pm 0.5$ & $7 \pm 0.4$ & $15 \pm 0.8$ & $9 \pm 0.5$ & $8 \pm 0.4$ & $10 \pm 0.5$ \\
\hline $2: 5$ & $12 \pm 0.6$ & $9 \pm 0.5$ & $12 \pm 0.6$ & $10 \pm 0.5$ & $13 \pm 0.7$ & $11 \pm 0.6$ & $10 \pm 0.5$ & $15 \pm 0.7$ \\
\hline $2: 6$ & $9 \pm 0.5$ & $9 \pm 0.5$ & $8 \pm 0.4$ & $9 \pm 0.5$ & $17 \pm 0.9$ & - & $8 \pm 0.4$ & $15 \pm 0.7$ \\
\hline $2: 7$ & $10 \pm 0.5$ & $11 \pm 0.6$ & - & $8 \pm 0.4$ & $15 \pm 0.8$ & - & - & $11 \pm 0.6$ \\
\hline $3: 4$ & $11 \pm 0.6$ & $12 \pm 0.6$ & - & - & $12 \pm 0.6$ & - & - & $12 \pm 0.6$ \\
\hline $3: 5$ & $13 \pm 0.7$ & $10 \pm 0.5$ & - & - & $11 \pm 0.6$ & - & - & $14 \pm 0.7$ \\
\hline $3: 6$ & $13 \pm 0.7$ & $11 \pm 0.6$ & $12 \pm 0.6$ & $9 \pm 0.5$ & $13 \pm 0.7$ & $10 \pm 0.5$ & $10 \pm 0.5$ & $13 \pm 0.7$ \\
\hline $3: 7$ & $11 \pm 0.6$ & $13 \pm 0.7$ & $12 \pm 0.6$ & $9 \pm 0.5$ & $12 \pm 0.6$ & $11 \pm 0.6$ & $11 \pm 0.6$ & $12 \pm 0.6$ \\
\hline $4: 5$ & $10 \pm 0.5$ & $10 \pm 0.5$ & $9 \pm 0.5$ & - & $13 \pm 0.7$ & $10 \pm 0.5$ & $10 \pm 0.5$ & $10 \pm 0.5$ \\
\hline $4: 6$ & $11 \pm 0.6$ & - & - & - & $18 \pm 0.9$ & - & - & - \\
\hline $4: 7$ & $12 \pm 0.6$ & $12 \pm 0.6$ & $13 \pm 0.7$ & - & $15 \pm 0.8$ & - & - & $14 \pm 0.7$ \\
\hline $5: 6$ & $10 \pm 0.5$ & $11 \pm 0.6$ & $9 \pm 0.5$ & $7 \pm 0.4$ & - & - & $10 \pm 0.5$ & $13 \pm 0.7$ \\
\hline $5: 7$ & $12 \pm 0.6$ & - & - & - & - & - & - & $11 \pm 0.6$ \\
\hline $6: 7$ & $12 \pm 0.6$ & - & - & - & $11 \pm 0.6$ & $9 \pm 0.5$ & - & $12 \pm 0.6$ \\
\hline Lincolin $(10 \mu \mathrm{g})$ & $10 \pm 0.5$ & $9 \pm 0.5$ & $8 \pm 0.4$ & $7 \pm 0.4$ & $16 \pm 0.8$ & $13 \pm 0.7$ & $10 \pm 0.5$ & $10 \pm 0.5$ \\
\hline $\begin{array}{c}\text { Streptomycin } \\
(75 \mu \mathrm{g})\end{array}$ & $15 \pm 0.8$ & $17 \pm 0.9$ & $13 \pm 0.7$ & $12 \pm 0.6$ & $16 \pm 0.8$ & $15 \pm 0.8$ & $14 \pm 0.7$ & $13 \pm 0.7$ \\
\hline $\begin{array}{c}\text { Gentamycin } \\
(30 \mu \mathrm{g}))\end{array}$ & $16 \pm 0.8$ & $15 \pm 0.8$ & $8 \pm 0.4$ & $9 \pm 0.5$ & $16 \pm 0.8$ & $8 \pm 0.4$ & $10 \pm 0.5$ & $18 \pm 0.9$ \\
\hline
\end{tabular}


Table 3: Chemical properties of the potent compounds obtained by GC/MS analysis

\begin{tabular}{|c|c|c|c|c|c|c|}
\hline $\begin{array}{c}\text { Algal } \\
\text { sample }\end{array}$ & $\begin{array}{l}\text { Library/ ID } \\
\text { (Analyte } \\
\text { identified) }\end{array}$ & $\begin{array}{l}\text { Molecular } \\
\text { Formula } \\
\text { (M.F.) }\end{array}$ & $\begin{array}{l}\text { Molecular } \\
\text { weight } \\
\text { (M.Wt.) }\end{array}$ & $\begin{array}{l}\text { Match } \\
\text { Quality } \\
(\%)\end{array}$ & $\mathbf{R}_{f}$ & Chemical Structure \\
\hline \multirow{2}{*}{$\begin{array}{l}\frac{1}{0} \\
8 \\
0 \\
0 \\
0 \\
5\end{array}$} & $\begin{array}{c}\text { Methyl } \\
\text { isostearate }\end{array}$ & $\mathrm{C}_{19} \mathrm{H}_{38} \mathrm{O}_{2}$ & 298.50 & 91 & 0.73 & \\
\hline & Palmitic acid & $\mathrm{C}_{16} \mathrm{H}_{32} \mathrm{O}_{2}$ & 256.42 & 53 & 0.90 & $\mathrm{OH}$ \\
\hline 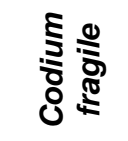 & $\begin{array}{l}\text { Hexadecanoic } \\
\text { acid; methyl } \\
\text { ester }\end{array}$ & $\mathrm{C}_{17} \mathrm{H}_{34} \mathrm{O}_{2}$ & 270.45 & 93 & 0.68 & 0 \\
\hline \multirow{2}{*}{ 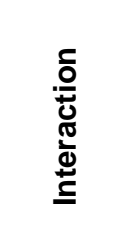 } & $\begin{array}{l}\text { Hexadecanoic } \\
\text { acid; methyl } \\
\text { ester }\end{array}$ & $\mathrm{C}_{17} \mathrm{H}_{34} \mathrm{O}_{2}$ & 270.45 & 90 & 0.64 & 0 \\
\hline & Palmitic acid & $\mathrm{C}_{16} \mathrm{H}_{32} \mathrm{O}_{2}$ & 256.42 & 95 & 0.96 & $\mathrm{OH}$ \\
\hline
\end{tabular}

* The nearest library standard.

Table 4: Antibacterial activities of the compounds separated from the two potent marine algal extracts and their interaction.

\begin{tabular}{|c|c|c|c|c|c|c|c|c|c|}
\hline \multirow[b]{3}{*}{ 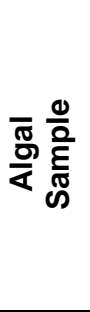 } & \multirow[b]{3}{*}{$\begin{array}{l}\frac{\delta}{d} \\
\frac{\pi}{\pi} \\
\frac{2}{\sigma} \\
\frac{0}{0} \\
\frac{0}{0} \\
\text { 心 }\end{array}$} & \multicolumn{8}{|c|}{ Inhibition zone diameter $(\mathrm{mm})$} \\
\hline & & \multicolumn{4}{|c|}{ Fish pathogens } & \multicolumn{4}{|c|}{ Human pathogens } \\
\hline & & $\frac{\frac{\pi}{8}}{\frac{8}{\pi}}$ & 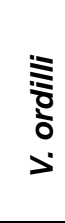 & 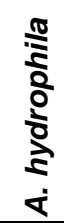 & خ & × & 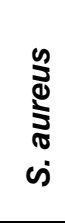 & نे & 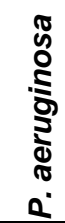 \\
\hline \multirow{2}{*}{$\begin{array}{l}\frac{\pi}{0} \\
0 \\
0\end{array}$} & $\begin{array}{c}\text { Methyl } \\
\text { isostearate }\end{array}$ & 11 & 9 & - & - & 9 & - & - & 9 \\
\hline & Palmitic acid & 17 & 11 & 9 & 9 & 16 & 9 & 9 & 10 \\
\hline కิ & $\begin{array}{l}\text { Hexadecanoic } \\
\text { acid; methyl } \\
\text { ester }\end{array}$ & 12 & 10 & 9 & - & 11 & - & - & 10 \\
\hline \multirow{2}{*}{ 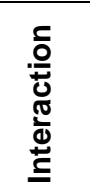 } & $\begin{array}{l}\text { Hexadecanoic } \\
\text { acid; methyl } \\
\text { ester }\end{array}$ & 7 & - & 7 & 9 & 11 & - & 10 & 11 \\
\hline & Palmitic acid & 18 & 15 & 10 & 9 & 15 & 9 & 10 & 13 \\
\hline
\end{tabular}


(A)

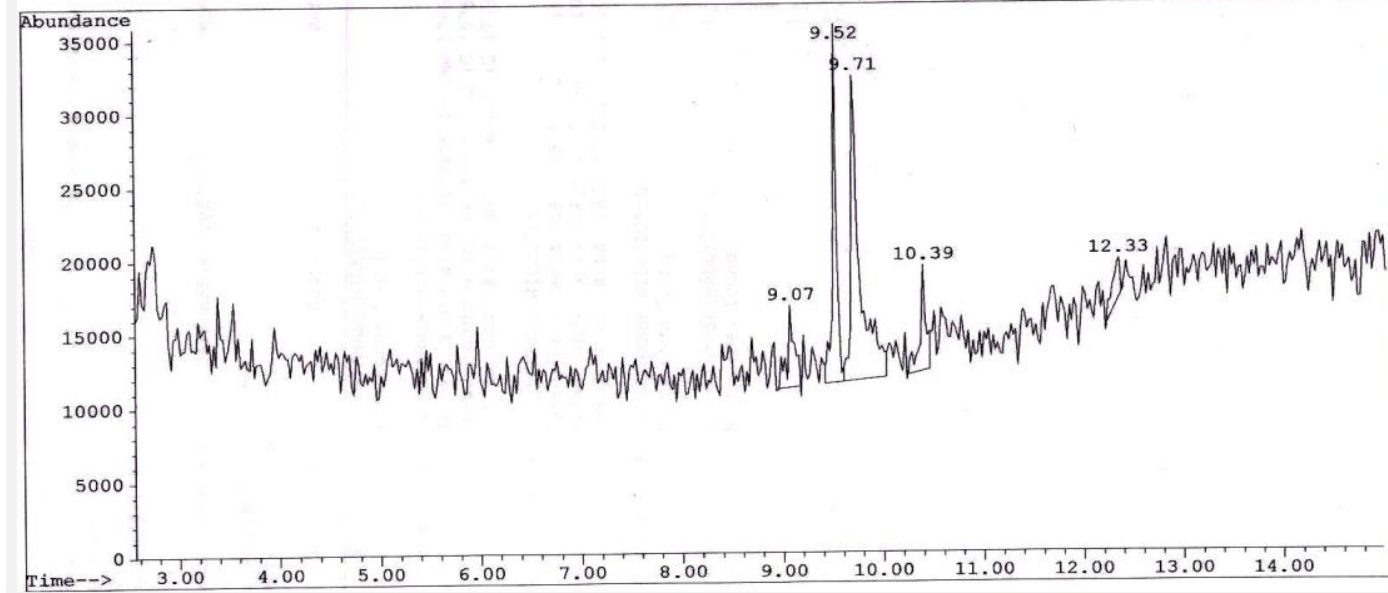

(B)

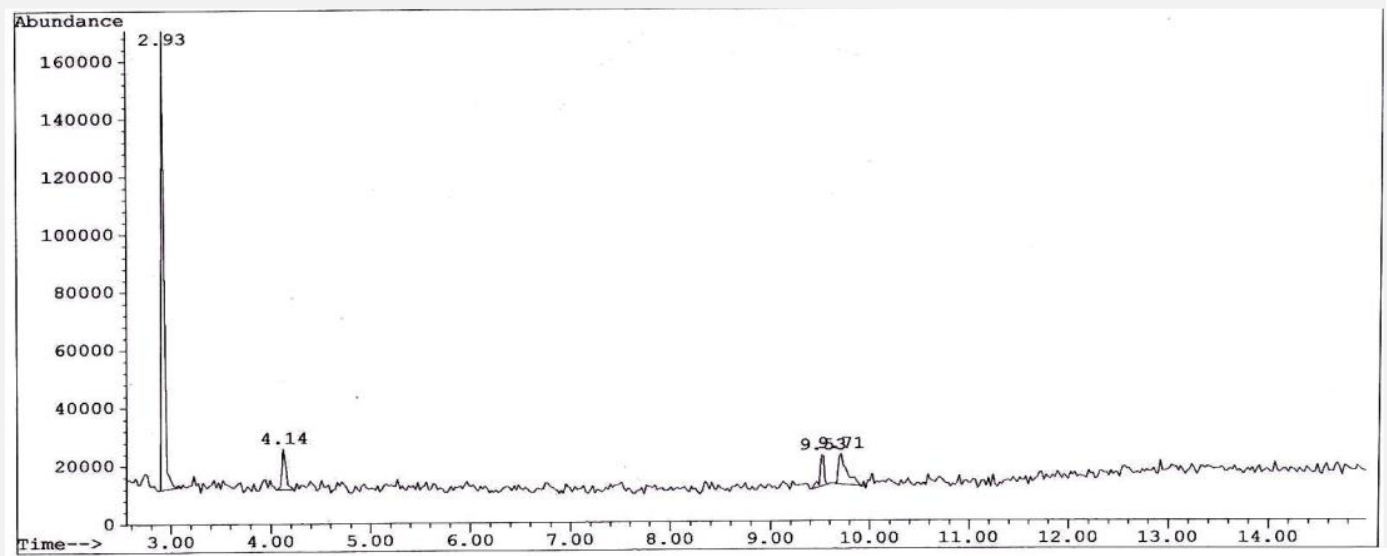

(C)

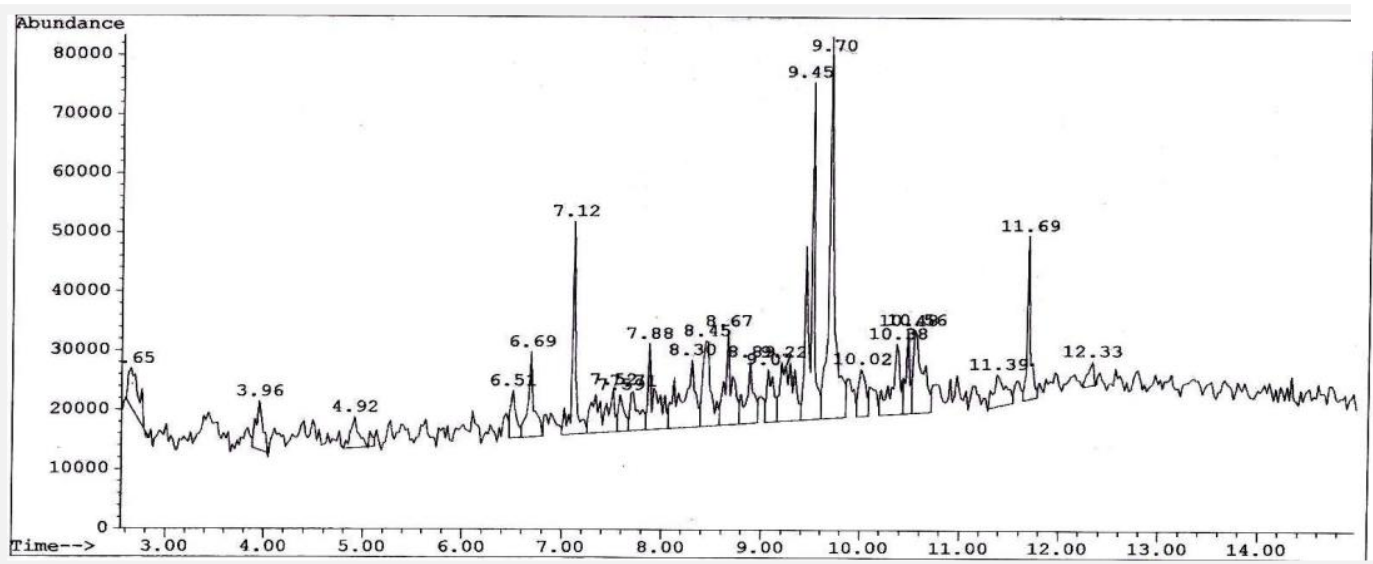

Figure 1: Gas chromatogram profile of Udotea sp. (A); Codium fragile (B) methanolic extracts and their interaction (C) showing their major compounds at different retention times. 


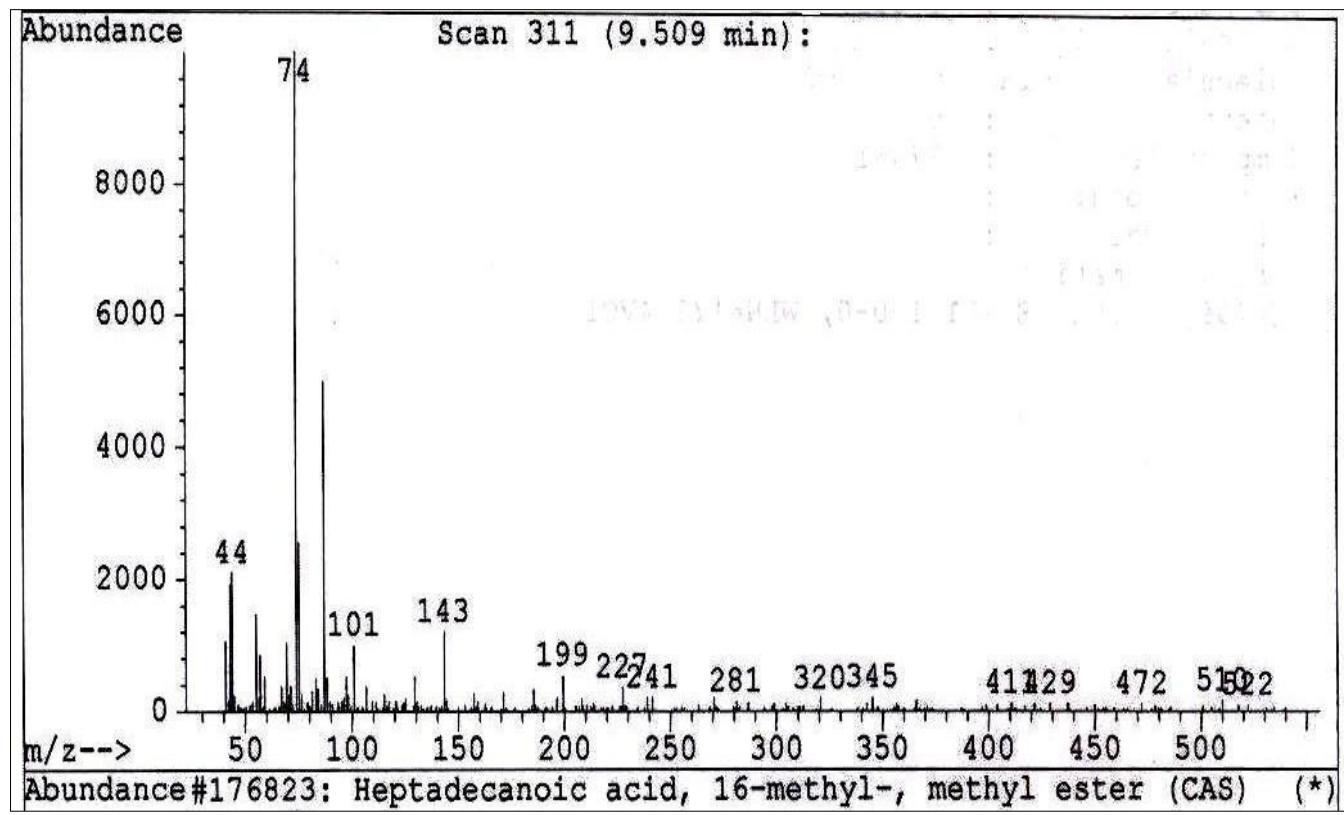

(A)

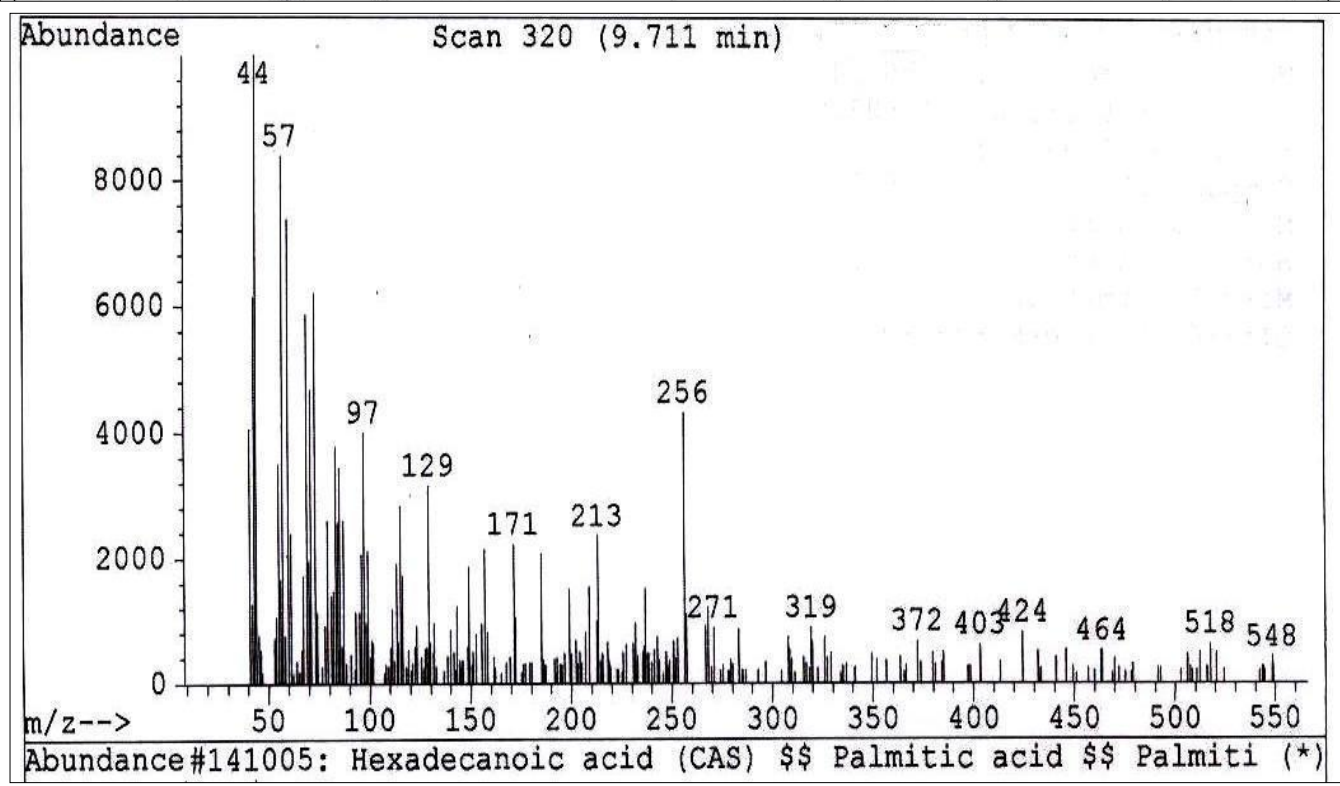

(B)

Figure 2: Mass-Spectrum of methyl isostearate (A) and Palmitic acid (B) in Udotea methanolic extract 


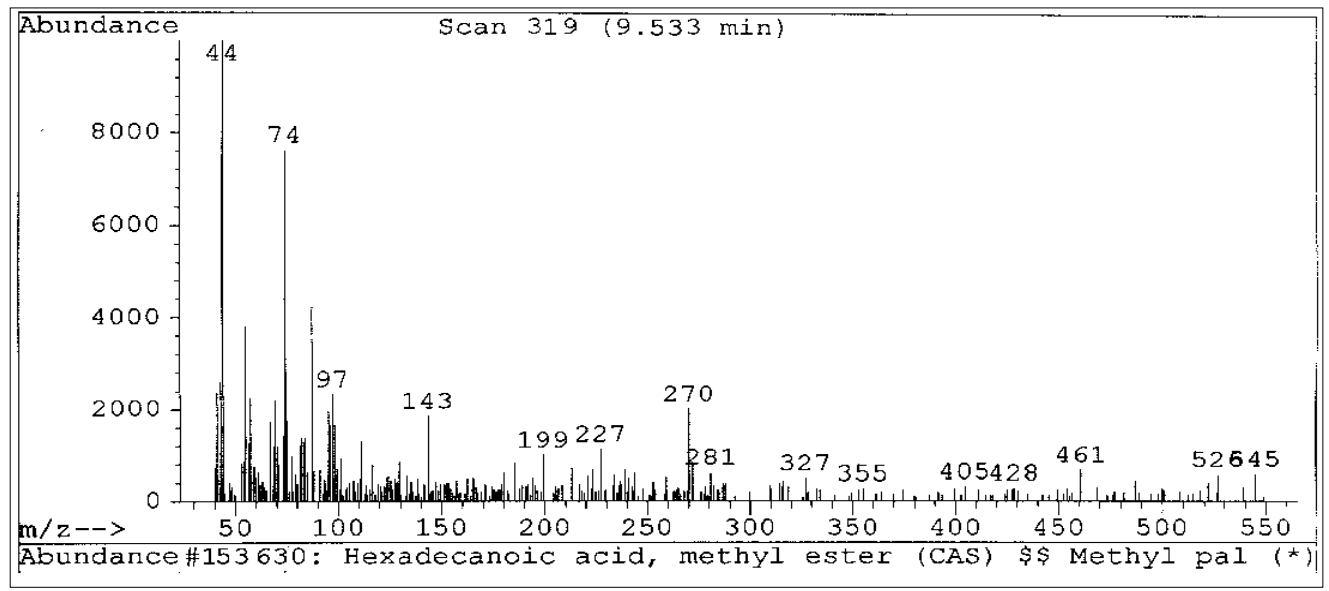

Figure 3: Mass-Spectrum of Hexadecanoic acid; methyl ester in Codium fragile methanolic extract.

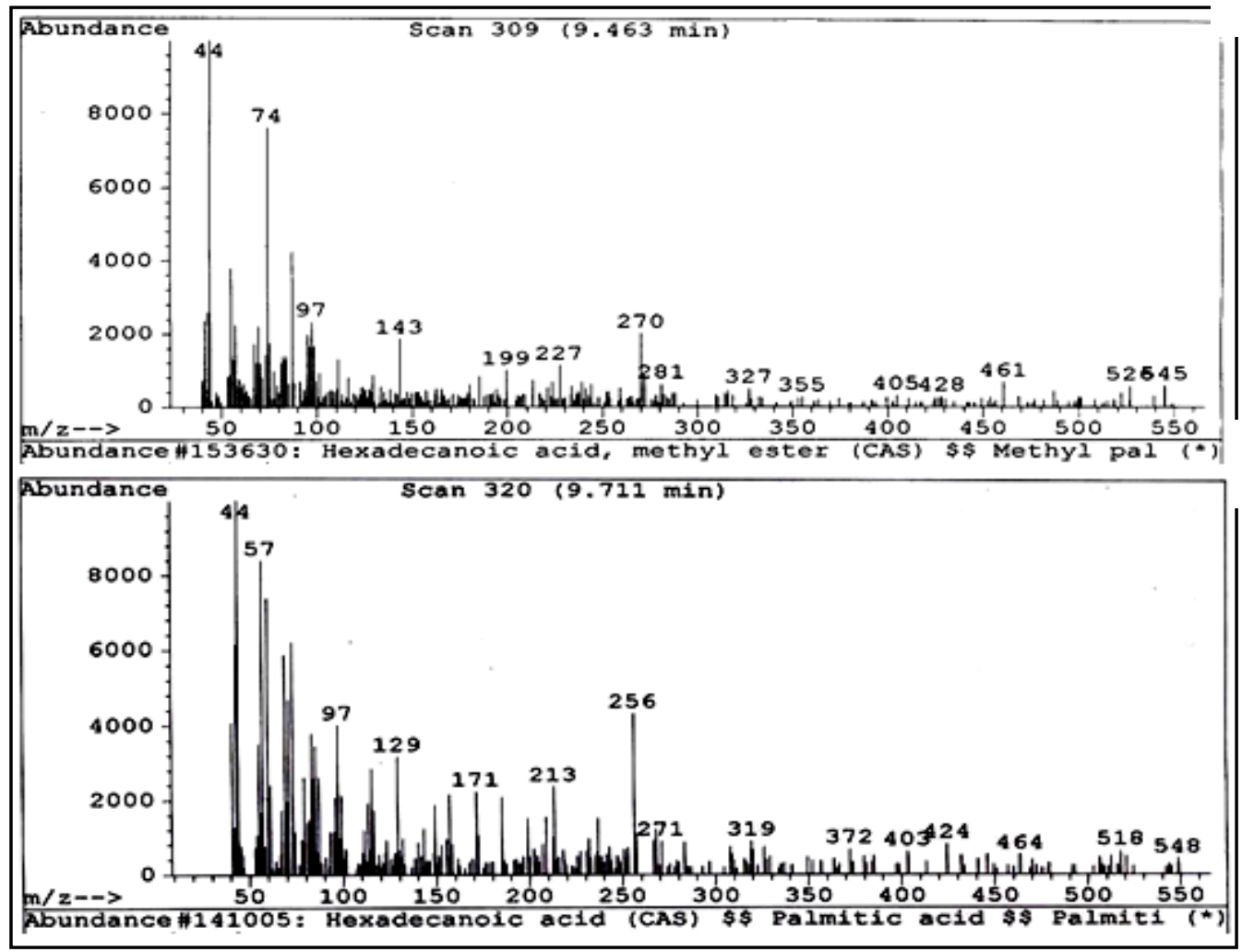

(B)

Figure 4: Mass-Spectrum of Hexadecanoic acid; methyl ester (A) and Palmitic acid $(B)$ in the interaction of the two extracts. 

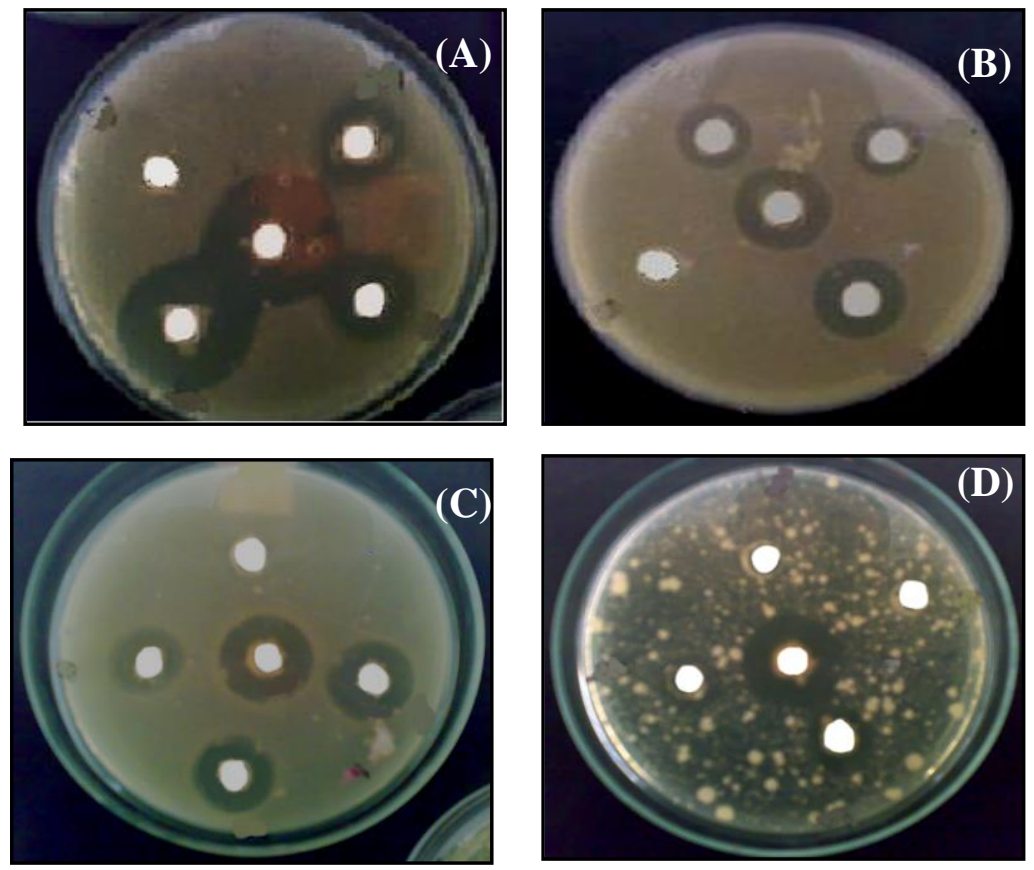

Figure 5: The inhibition zones of the antibacterial activity caused by the compounds separated from the potent algal extracts against $1.2 \times 10^{3} \mathrm{CFU} / \mathrm{ml}$ of $E$. tarda $(\mathrm{A}) ; V$. ordilli (B); K. pneumonia (C) and $P$. aeroginosa (D).

\section{REFERENCES}

1. Wu JH; Wu AM; Tsai CG; Chang XY; Tsai SF; Wu TS. Contribution of fucose-containing capsules in Klebsiella pneumonia to bacterial virulence in mice. Exp Boil Med. 2008; 233 (1):64-70.

2. Sood S; Amatya R; Malhotra M; Das BK; Kapil A. Profile of bacterial isolates from suspected cases of infective endocarditis (IE): a retrospective study in a north Indian tertiary care hospital. J Comm Dis. 2006; 38 (4):363-67.

3. Lauro FV; Guillermo CR; Francisco DC; María del Carmen LR; Rosa M;
Escalante M; Linda V; García F. Evaluation and characterization of antimicrobial properties of pregnenolone-derivatives on Staphylococcus aureus; Klebsiella pneumoniae and Escherichia coli Rev Latin Microbiol. 2008; 50 (1-2): 13-18.

4. Savan R; Igarashi A; Matsuoka S; Sakai M. Sensitive and rapid detection of Edwardsiellosis in fish by a loopmediated isothermal amplification method. Appl Environ Microbiol. 2004; 70:621-24.

5. Wang IK; Kuo HL; Chen YM; Lin CL; Chang HY; Chuang FR; Lee $\mathrm{MH}$. 
Extraintestinal manifestations of Edwardsiella tarda infection. Int $\mathrm{J}$ Clin Pract. 2005; 59(8):917-21.

6. Gonzalez CJ; Santos JA; Lopez MLG; Otero A. Virulence markers in Aeromonas hydrophila and Aeromonas veronii biovar sorbia isolates from fresh water fish and from a diarrhea case. J Appl Microbiol. 2002; 93:414-19.

7. Jones $M$; Cockerill DJ; Birkbeck TH; Cox DI. Clinical infection in cod (Gadus morhua L.) in Scotland by Vibrio anguillarum- a case history. Bull Euro Assoc Fish Pathol. 2000; 20:125-28.

8. Demain AL; Sanchez S. Microbial drug discovery: 80 years of progress. J Antib. 2009; 62:5-16.

9. Smith P; Hiney MP; Samuelsen OB. Bacterial resistance to antimicrobial agents used in fish farming. Ann Rev Fish Dis. 1994; 4:273-313.

10. Santoso J; Yumiko Y; Takeshi S. Antioxidant activity of methanol extracts from Indonesian seaweeds in an oil emulsion model. Fish Sc. 2004; 70:183-88.

11. Choudhury S; Sree1 A; Mukherjee SC; Pattnaik P; Bapuji M. In Vitro Antibacterial activity of extracts of selected marine algae and mangroves against fish pathogens. Asi Fish Sc. 2005; 18:285-94.

12. Kandhasamy $M$; Arunachalam KD. Evaluation of in vitro antibacterial property of seaweeds of southeast coast of India. Afri J Biotechnol. 2008; 7 (12): 1958-61.

13. Abd El-Baky HH; El Baz FK; El-Baroty GS. Evaluation of marine alga Ulva Lactuca L. as a source of natural preservative ingredient. Elec J Environ Agri Food Chem. 2008; 7 (11): 3353-67.
14. Ibtissam $C$; Hassane $R$; José $M$; Francisco DSJ; Antonio GVJ; Hassan $B$; Mohamed K. Screening of antibacterial activity in marine green and brown macroalgae from the coast of Morocco. Afri J Biotechnol. 2009; 8 (7): 1258-62.

15. Bauer AW; Kirby WM; Sherris JC; Turck M. Antibiotic susceptibility testing by a standardized single disk method. Americ J Clin Pathol. 1966; 45:493-96.

16. Streuli JC; Exner GU; Reize CL; Merkofer C; Scott CP; Zbinden R. In Vitro Inhibition of coagulasenegative Staphylococci by Vancomycin/Aminoglycoside-loaded cement spacers. Infec. 2006; 34: 81-6.

17. Wiley J.; Wiley Registry of mass spectral data; 8th edition "software" Wiley's scientific; technical; and medical databases. 2006.

18. Liao WR; Lin J-Y; Shieh WY; Jeng WL; Huang R. Antibiotic activity of lectins from marine algae against marine vibrios. J Indust Microbiol Biotechnol. 2003; 30:433-39.

19. Salvador N; Gomez-Garreta A; Lavelli L; Ribera L. Antimicrobial activity of Iberian macroalgae. Sci Mar. 2007; 71:101-14.

20. Punín CMO; Lage YMA. Determination of aliphatic hydrocarbons in the alga italic Himanthalia elongate. Ecotoxicol Environ Saf. 2004; 57 (2): 226-30

21. Santoyo S; Rodríguez-Meizoso I; Cifuentes A; Jaime L; García-Blairsy RG; Señoran FJ; Ibáñez E. Green processes based on the extraction with pressurized fluids to obtain potent antimicrobials from Haematococcus pluvialis microalgae. Food Sci Technol. 2009; 42(7): 1213-18 